\title{
Welding of Normalized Heat Treated Steels S355NL Large Thicknesses by Method FCAW
}

Marie Kolaříková, Ladislav Kolařík, Karel Kovanda, Rudolf Hrabina

CTU in Prague, Faculty of Mechanical Engineering, Department of Manufacturing Technology, Technická 4, Praha 6, 166 07, Czech Republic, marie.kolarikova@fs.cvut.cz

Welding of thick plates of heat treated steels present difficulties, because of decrease of mechanical properties caused by welding heat input. At Welding Department of FME of CTU in Prague experiments researching influence of use cored wire on FCAW welding of thick plate welding was done. Plate of fine grained structural steel S355NL of thickness $50 \mathrm{~mm}$ used for crane fabrication was subjected to FCAW welding. Double-V butt joint was welded using flux cored wire (Coreweld $46 \mathrm{LS}$ ) as filler metal. The welded crane structure needs WPS certification, so WPQR tests were done. The paper presents welding procedures and results of non-destructive (visual, magnetic and radiographic testing) and destructive (tensile test, Charpy impact test, metallography, hardness measurement and bending test) tests of weld joint.

Keywords: FCAW, fine grained steel, S355 NL, X-rays, visual testing

\section{Acknowledgement}

The research was financed by the Czech Ministry of Education, Youth and Sport within the frame of project SGS CVUT 2010 - OHK2-038/10.

\section{References}

[1] PILOUS, V. at all. (1999). Vysokopevné mikrolegované jemnozrnné oceli a jejich svařitelnost. Vodní stavby a.s., pp. 35, Plzen̆

[2] KOLAŘÍK, L., KOLǍ̌íKOVÁ, M., VONDROUŠ, P. (2012). The choice of parameters for welding of steel S355NL, Annals of DAAAM for 2012 and Proceedings, Vienna

[3] PILOUS, V.(2011). Welding of Fine-Grained Steels S355 N in Protective Gases Using the Wires OK AristoRod 12, Konstrukce, 12/ 2011, ISSN 1803-8433

[4] SEFERIAN, D. (1959). Métallurgie de la Soudure, Dunod, Pris,

[5] PILOUS, V.(2012) Heat Treatment of Welded Structures of Common Carbon Structural Steel S235 and HighStrength Low-Alloy Structural Steel S355 in Accordance With ISO 17663, Konstrukce 05, ISSN 1803-8433

[6] JANOVEC, J., PILOUS, V (2011). Using the Normalized Heat-Treated Steels S355NL and Thermo-Mechanically Treated S355ML, Konstrukce, 11/2011, ISSN 1803-8433

[7] SVÚM a.s., Zkušební protocol č. 2445/12, Praha, 2012

[8] KUKLÍK, V. (2012). Inspekční zpráva č. 63-9262, SZU, s.p., Brno,

[9] KOVANDA, K., KOLAŘÍK, L., VÁLOVÁ, M., KOPŘIVA, J. (2011). Vliv ochranných plynů při GMAW svařování hliníkových slitin typu EN AW 7022, Strojírenská technologie, XVI/4, pp. 25 - 32. ISSN 1211-4162

[10] CHOŤEBORSKÝ, R., NAVRÁTILOVÁ, M. (2011). Experimentální posouzení vlivu navařovacích parametrů na promísení návarové housenky, Strojírenská technologie, XVI/1, pp. 44 - 49. ISSN 1211-4162

[11] KOLǍ̌íK, L., KOVANDA, K., VÁLOVÁ, M., DUNOVSKÝ, J. (2011). Posouzení vlivu přídavného materiálu na pórovitost svarových spojů při MIG svařování vytvrditelných hliníkových slitin typu AlMgSi, Strojírenská technologie, XVI/1, pp. 54 - 60. ISSN 1211-4162

[12] HUDEC, Z. (2012). Gas Metal Rapid Arc Welding Potential, Manufacturing Technology, Volume 12, December, pp. 113 - 118, ISSN 1213-2489

[13] KOVANDA, K., HOLUB, L., KOLAŘÍK, L., KOLAŘÍKOVÁ, M., VONDROUŠ, P. (2012). Experimental Verification of FEM Simulation of GMAW Bead on Plate Welding, Manufacturing Technology, Volume 12, June, pp. 30 - 33, ISSN 1213-2489 